\title{
The Influence of Service Quality and Company Image to Customer Loyalty through Corporate Customer Satisfaction on XXX Group
}

\author{
Hastuti Sri Rahayu ${ }^{1}$, Paham Ginting ${ }^{2}$, Beby Karina Fawzeea ${ }^{3}$ \\ ${ }^{1,2,3}$ Department of Management, University of Sumatera Utara, Medan, Indonesia.
}

Corresponding Author: Hastuti Sri Rahayu

\begin{abstract}
To increase economic growth through infrastructure development in Indonesia, the Government is accelerating projects that are considered strategic and have high urgency to be realized in a short period. XXX Group which is one of the large cement companies in Indonesia is a great opportunity because PSN will use a large amount of cement in its work. But XXX Group is not alone in the cement market, many competitors compete to get PSN (Project National Stategic), so each company uses a surefire strategy in marketing its products both in terms of service quality and by improving the company's image in the eyes of customers so that customers are satisfied with XXX Group and will increase customer loyalty. The purpose of this research is to know and analyze the influence of service quality and company image directly on customer loyalty and the indirect influence of service quality and company image on customer loyalty through customer satisfaction at XXX Group. The type of data used is quantitative in the form of primary and secondary data. The population of this study is a company that makes purchases as many as 42 projects and the sample recall used is a saturated sample so that all populations are used into samples. The data analysis method used is to use the structural equation model by using Smart PLS 3.0 program. The results showed the quality of service has a positive and significant effect on customer loyalty, the company's image has a positive and significant effect on customer loyalty. The quality of service has a positive and significant effect on customer satisfaction, the image has a positive and significant effect on customer satisfaction. Customer satisfaction has
\end{abstract}

a positive and significant effect on customer loyalty. Customer satisfaction mediates the influence of service quality and company image in shaping customer loyalty. Coefficient of determining the influence of service quality and company image on customer loyalty (R2) by $97.6 \%$ and coefficient of determining the influence of service quality and company image on customer loyalty through customer satisfaction (R2) by $99.0 \%$

Keywords: Service Quality, Company Image, Customer Satisfaction, Customer Loyalty.

\section{INTRODUCTION}

In order to increase economic growth through infrastructure development in Indonesia, the Government is making efforts to accelerate projects that are considered strategic and have high urgency to be realized in a short period of time. National Strategic Project (PSN) which includes the construction of toll roads, dams and airports. PSN does not only concentrate on the island of Java but has also been promoted outside Java such as on the Sumatra Island toll road, the Lausimeme Dam in North Sumatra, the airport in Makassar and others. The company uses an integrated marketing strategy with the aim of increasing consumer satisfaction in making choices. Changes in the business environment accompanied by economic globalization have an impact on customers, competition, and change (Pratiwi, 2008). Currently the customer is in control of the business, previously the producer who 
determines what products and services should be provided in the market. Thus, consumer behavior can be used as a tool to see new opportunities that arise or to anticipate this intense competition. To develop the business, the strategy carried out by the XXX Group is by observing customer demand for the products offered. Companies must always follow the desires and needs of customers who are always changing, and create products that are designed to meet consumer needs so that profits will be obtained from products that are successfully sold. The ultimate goal of the marketing concept is satisfaction oriented so that customers remain loyal to the products offered. According to (Hasan, 2009) customer satisfaction is a consumer feeling as a response to products that have been consumed. Customer satisfaction plays a mediator role on customer loyalty, this shows the relationship between customer satisfaction and customer loyalty (Teimouri et al, 2016). The company believes in customer satisfaction as a guarantee of success in the future.

A company needs to develop a service and product strategy so that consumers feel satisfied using the products issued by the company. Consumers who are satisfied with a company's products and services, tend to continue to buy and use the product and tell others about a pleasant consumer experience with the product. Loyalty is directly influenced by customer satisfaction (Paul et al, 2016). The results of the study (Dennisa, et al, 2016) state that customer satisfaction has a positive and significant effect on customer loyalty, while research (Mutmainnah, 2017) states that customer satisfaction has no effect on customer loyalty.

In the company, the quality of service has a very important role, therefore, with good service quality by the company, it is hoped that consumers will be satisfied with the products offered and will become loyal customers. Service quality is centered on a company's efforts to meet the needs and desires of customers and the provision of delivery to be balanced with the expectations of customers (Simamora, 2003). The company's service quality is a form of customer assessment of the level of service received (perceived services) with the level of service expected (excepted service). Customers will be generous to the company if the company has the ability to create and maintain good emotional relationships in the long term with its customers, the company provides the best quality service that is able to win the hearts of customers so as to make customers loyal and repurchase products from the company. The results of the study (Karyose, et al, 2018) state that service quality has a positive and significant effect on customer loyalty, while research (Normasari, et al, 2013) states that service quality has no effect on customer loyalty. Building a leading cement company image that is good in general in the eyes of the community or in the eyes of stakeholders requires creativity and hard work so that people continue to use the company's products. So the company must try to provide products that are in accordance with the expectations of the community and stakeholders. Thus, the company will have a good image in the eyes of the public. The results of the study (Safitri, et al, 2016) state that company image has a positive and significant effect on customer loyalty, while research (Hidayat \& Firdaus, 2014) states that company image has no effect on customer loyalty. So to prove the influence of corporate image on loyalty, it is necessary to re-do research on the influence of corporate image on loyalty in the XXX Group. Companies can develop various strategies to influence customer loyalty. Several strategies to influence customer loyalty is to improve the quality of service and corporate image used by the XXX Group in influencing customer responses or reactions to its target market. 


\section{LITERATURE REVIEW Service Quality}

Service quality is the expected level of excellence and control over the level of excellence to meet customer desires. Service quality is a measure of how well the level of service provided is able to meet consumer expectations. According to Tjiptono (2011), there are several factors that can cause poor service quality, such as simultaneous product and consumption, high labor intensity, inadequate internal customer support, communication gaps, treating customers the same way, expansion and Excess Service Development and Short Term Business Vision. According to Tjiptono (2011), there are five dimensions and indicators of service quality that must be met, namely Tangible, reliability, responsiveness, assurance and empathy.

\section{Company Image}

Image is the impression that a person feels about an object or item or the organization as a whole which will then be stored in the memory of consumers (Kotler \& Keller, 2014). Corporate image has several important objects, namely the impression of the object, the process of image formation, and reliable sources. Objects include companies, individuals, and people who are in them. Corporate image is one part that is considered important by companies, both large-scale companies and small-scale companies (Yustriany, 2017). The image of the company in a person's mind that comes from a collection of feelings, attitudes, ideas, and experiences about the company. These impressions can be positive or negative according to experience. Customers will recall that impression when they hear the name of the company (Suratno, et al, 2016). According to Kotler and Keller (2014), corporate image can be measured in the following ways: (1) Personality, the overall characteristics of the company that are understood by the target public such as trustworthy companies, companies that have social responsibility (2) Reputation, rights that have been exercised by the company and believed by the public to be based on experience and other parties such as the performance of the company's transaction security, (3) Values, values owned by a company in other words corporate culture such as management attitudes that care about customers, employees who are quick to respond to customer requests and complaints. (4) Corporate Identity, components that facilitate the introduction of the target public to the company such as logos, colors, and slogans.

\section{Customer loyalty}

The creation of satisfaction can provide several benefits including the relationship between the company and its customers to be harmonious, becoming the basis for repeat purchases and creating customer loyalty and word of mouth recommendations that benefit the company (Tjiptono, 2011). Loyalty is a deeply held commitment to repurchase or subscribe to a preferred product or service in the future despite situational influences and marketing efforts having the potential to cause consumers to switch to another product (Kotler \& Keller, 2013). It can be concluded that customer loyalty will arise if the customer feels satisfaction or enjoyment when using the goods or services and in the end the customer will then make a repeat purchase of the product. In addition, while customers repurchase goods or services, loyal customers will inadvertently influence the surrounding environment to use the purchased or consumed goods or services.

According to Kotler \& Keller, 2012, Loyalty can be measured in the following ways (1) Repeat Purchase, (2) Retention (3) Referrals.

\section{Customer satisfaction}

Satisfaction is a person's feelings of pleasure or disappointment that arise after comparing his perception or impression of the performance of a product and expectations. Customer satisfaction is the level of one's feelings after comparing the 
perceived performance compared to expectations (Kotler \& Keller 2014). Basically, the notion of customer satisfaction includes the difference between the level of importance and performance or perceived results. The creation of consumer satisfaction can provide benefits, including harmonious relations between the company and customers, providing a good basis for repeat purchases and creating customer loyalty, and forming a word-of-mouth recommendation that is profitable for the company.

According to Irawan (2008), indicators of customer satisfaction, namely (1) Feeling satisfied with the services provided, (2) Fulfillment of customer expectations after buying the product, (3) Satisfaction with facilities, (4) Overall satisfaction

\section{MATERIALS \& METHODS}

This research uses associative research. According to Sugiyono (2011), associative research is research that aims to determine the relationship between two or more variables to study, describe, and see the influence between the variables formulated on the research hypothesis. This study uses descriptive data analysis techniques and PLS-SEM. The population in this study is the XXX Group's corporate customers (BUMN and Private) in North Sumatra who make direct purchases, totaling 42 customers. The criteria for sampling using saturated samples, where the entire population is used as the research sample.

\section{Statistical Analysis}

\section{RESULT \\ Respondent's Descriptive}

The results of the descriptive analysis of the respondents showed that the respondents in this study were male more than female, for age, indicating that those who answered the statements on the questionnaire in this study were the dominant respondents aged over 30 years. Based on education, it is known that S1 education is more dominant.

\section{Data Analysis}

Table 1: Research Hypothesis Testing Results

\begin{tabular}{|c|c|c|c|c|c|}
\hline No & Hypothesis & $\begin{array}{l}\text { Original } \\
\text { Sample }(\mathbf{O})\end{array}$ & $\begin{array}{l}\text { T Statistics } \\
(\mid \text { O/STDEV } \mid)\end{array}$ & $\begin{array}{l}\text { P } \\
\text { Values }\end{array}$ & Result \\
\hline 1 & $\begin{array}{l}\text { Service quality has a positive and significant effect on customer } \\
\text { loyalty. }\end{array}$ & 0,457 & 4,222 & 0,002 & Accepted \\
\hline 2 & $\begin{array}{l}\text { Company image has a positive and significant effect on customer } \\
\text { loyalty. }\end{array}$ & 0,280 & 2,543 & 0,000 & Accepted \\
\hline 3 & $\begin{array}{l}\text { Service quality has a positive and significant effect on customer } \\
\text { satisfaction }\end{array}$ & 0,498 & 3,025 & 0,001 & Accepted \\
\hline 4 & $\begin{array}{l}\text { Service quality has a positive and significant effect on customer } \\
\text { satisfaction }\end{array}$ & 0,469 & 2,879 & 0,000 & Accepted \\
\hline 5 & $\begin{array}{l}\text { Service quality has a positive and significant effect on customer } \\
\text { loyalty through customer satisfaction. }\end{array}$ & 0,133 & 1,999 & 0,046 & Accepted \\
\hline 6 & $\begin{array}{l}\text { Company image has a positive and significant effect on customer } \\
\text { loyalty through customer satisfaction. }\end{array}$ & 0,125 & 2,072 & 0,039 & Accepted \\
\hline
\end{tabular}

Based on Table 1, it shows that service quality directly has a positive and significant effect on customer loyalty. Hypothesis 1 in the study was accepted. Furthermore, Table 4.18 shows that the company's image directly has a positive and significant effect on customer loyalty. Hypothesis 2 in the study was accepted. Service quality has a positive and significant effect on the quality of customer satisfaction. Thus, Hypothesis 3 research is accepted. Company image has a positive and significant effect on customer satisfaction. Thus hypothesis 4 is accepted. The indirect effect of service quality on customer loyalty through customer satisfaction is a positive and significant effect. Thus Hypothesis 5 research is accepted. The indirect effect of corporate image on customer loyalty through 
customer satisfaction also shows a positive and significant effect. Thus Hypothesis 6 research is accepted. Customer satisfaction has a positive and significant impact on customer loyalty. Then hypothesis 7 is accepted.

\section{DISCUSSION}

\section{Influence of Service Quality on Customer Loyalty}

The results of the study provide empirical evidence that good service quality provided by the XXX Group will significantly increase customer loyalty (path coefficient $=0.217 ; \mathrm{p}$-value $=0.002$ ). This finding confirms the theory of Dwiyana, et al (2015) which says loyalty to the community will appear if they are satisfied with the product or service used. Then the better the quality of services provided by the XXX Group will increase customer loyalty. The findings of this study are in line with the findings of Karyos, et al (2018), Mutmainnah (2017), and Enggarwati, et al (2017) which state that there is a positive relationship between service quality on customer loyalty.

\section{Influence of Company Image on Customer Loyalty}

The results provide empirical evidence that corporate image has a positive and significant effect on customer loyalty (path coefficient $=0.193$; $\mathrm{p}$-value $=0.001$ ) . These results indicate that the company's image has a positive and significant effect on customer loyalty. These findings indicate that the better the company's image, the more loyal customers will be. It is very important to maintain a strong corporate image in order to attract and retain consumers and also keep them loyal to the company (Jasfar \& Kristaung, 2012).

The findings of this study are in line with research conducted by (Mutmainnah, 2017) which found that company image has a positive effect on customer loyalty. These results are also supported by research conducted (Karyose, et al, 2018) which states that company image affects customer loyalty.

\section{Influence of Service Quality on Customer Satisfaction}

The results of the study provide empirical evidence that statistically, there is a positive and significant effect of service quality on customer satisfaction (path coefficient $=0.610 ; \mathrm{p}$-value $=0.000)$. The quality of service provided refers to the goal of customer satisfaction. Thus, good service quality should be achieved through a good service delivery process.

This study supports previous studies which state that there is a positive relationship and influence of service quality on customer satisfaction (Setyowati \& Wiyadi, 2017); Pangandaheng, 2017; Mutmainnah, 2017; Normasari, et al, 2013). The better the quality of service provided by the company, the higher the customer satisfaction.

\section{Influence of Company Image on Customer Satisfaction}

The results provide empirical evidence that corporate image has a positive and significant effect on customer satisfaction XXX Group (path coefficient = $0.384 ; \mathrm{p}$-value $=0.000)$. The company's image not only describes things whose status only attracts customers, but also relates to how the company maintains the culture in Indonesia by naming cement according to where the cement is produced. Companies that have a good corporate image, and are able to maintain culture will increase customer satisfaction. Research that found that company image has a positive effect on customer satisfaction is supported by research conducted by Pangandaheng (2017); Mutmainnah (2017); Hidayat \& Firdaus (2014); Safitri, et al (2016). Research that does not support this research is the research conducted by Saragih et.al which says that the company's image has no significant effect on customer satisfaction. 


\section{Influence of Service Quality on Customer Loyalty through Customer Satisfaction}

The results provide statistical empirical evidence that customer satisfaction mediates the effect of service quality on customer loyalty in the $\mathrm{XXX}$ Group (indirect effect $=0.241$; $\mathrm{p}$-value $=$ 0.002 ). The results of this study are in line with research conducted by Ramadhani (2016) and Safitri, et al (2016) which found that customer satisfaction was able to mediate the effect of service quality on customer loyalty. This shows that if the quality of service has been provided by the XXX Group company properly which results in the customer feeling satisfied, it will have an impact on the high level of customer loyalty at the XXX Group company. According to Cronin and Taylor (in Sondakh, 2014), the higher the level of service quality provided and perceived, the higher the level of customer satisfaction which will then result in customer loyalty.

\section{Influence of Corporate Image on Customer Loyalty through Customer Satisfaction}

The results provide statistical empirical evidence that customer satisfaction mediates the effect of corporate image on customer loyalty at the XXX Group company (indirect effect $=0.179$; $\mathrm{p}$ value $=0.002$ ). This shows that the $\mathrm{XXX}$ Group pays close attention to its corporate image the company's personality, company reputation, and company values, customers will feel satisfied with the company and will have an impact on customer loyalty. With a good corporate image in the customer's view, which significantly increases customer satisfaction will have an impact on customer loyalty. Ilhami (2013) states that company image can affect customer loyalty which is mediated by customer satisfaction. The results of this study are in line with research conducted by Safitri, et al (2016) which found that customer satisfaction was able to mediate the influence of corporate image on customer loyalty. This shows that if the company's image is good, it will result in customers feeling satisfied; it will have an impact on the high level of customer loyalty to the XXX Group company.

\section{CONCLUSION}

The research was conducted to answer all research hypotheses with the following conclusions:

1. Service quality has a positive and significant impact on customer loyalty XXX Group.

2. Company image has a positive and significant impact on customer loyalty XXX Group.

3. Service quality has a positive and significant impact on customer satisfaction XXX Group.

4. Company image has a positive and significant impact on customer satisfaction of the XXX Group.

5. Customer satisfaction has a positive and significant influence on customer loyalty XXX Group.

6. Service quality has a positive and significant influence on customer loyalty through customer satisfaction.

7. Company image has a positive and significant influence on customer loyalty through customer satisfaction.

\section{Acknowledgement: None}

\section{Conflict of Interest: None}

\section{Source of Funding: None}

\section{REFERENCES}

1. Dennisa, et al. (2016). Analisis Pengaruh Kualitas Produk, Kualitas Layanan, dan Citra Merek terhadap Loyalitas Pelanggan melalui Kepuasan Pelanggan sebagai Variabel Intervening (Studi pada Klinik Kecantikan Cosmedic Semarang). Diponegoro Journal of Management. Vol. 5 No. 3.

2. Dharmayanti. (2006). Analisis Dampak Service Performance dan Kepuasan Sebagai Moderating Variabel Terhadap Loyalitas Nasabah (Studi pada Nasabah Tabungan 
Bank Mandiri Cabnag Surabaya). Jurnal Manajemen Pemasaran. Vol. 1 No.1

3. Enggarwati, et al. (2017). Pengaruh Citra Merek, Kualitas Layanan Terhadap Loyalitas Pelanggan Yang Dimediasi Oleh Kepuasan Konsumen (Studi Pada Butik Zoya Di Kota Malang). Jurnal Bisnis dan Manajemen. Vol. 4 No. 1.

4. Hidayat, R., D., \& Firdaus, R., M. (2014). Analisis Pengaruh Kualitas Layanan, Harga, Kepercayaan, Citra Perusahaan, Dan Kepuasan Pelanggan Terhadap Loyalitas Pelanggan: (Studi Pada Pelanggan Telkom Speedy Di Palangka Raya). Jurnal Wawasan Manajemen. Vol. 2 No. 3.

5. Jasfar, F., \& Kristaung, R. (2012). The Effects of Retail Service Quality to the Relationship Marketing and Customer Retention.

6. Karyose, et al. (2018). Customer Loyalty: The Effect Of Service Quality, Corporate Image, Customer Relationship Marketing And Customer Satisfaction As Intervening Variable An Empirical Analysis Bank Customer In Malang City. International Journal of Research and Revew. Vol. 5 No. 5: 2349-9788

7. Kotler, P. \& Armstrong, G. (2012). Prinsipprinsip Pemasaran. 13. Jakarta: Erlangga.

8. Kotler, P. \& Keller. (2012). Manajemen Pemasaran. Jakarta: Erlangga.

9. Kotler, P. \& Keller, K. (2014). Marketing Management 15th Edition, Prentice Hall, Saddle River

10. Mutmainnah. (2017). Pengaruh Kualitas Layanan dan Citra Perusahaan Terhadap Kepuasan Dan Loyalitas Nasabah. Jurnal Manajemen dan Pemasaran Jasa. Vol. 10 No. 2: 2442-9732.

11. Normasari, et al. (2013). Pengaruh Kualitas Pelayanan Terhadap Kepuasan Pelanggan, Citra Perusahaan Dan Loyalitas Pelanggan. Jurnal Administrasi Bisnis. Vol. 6 No. 2.

12. Pangandaheng, F. (2019). Pengaruh Kualitas Layanan Dan Citra Perusahaan Terhadap Kepuasan Pelanggan Dan Dampaknya Terhadap Loyalitas Pelanggan
Pada PT. Hadji Kalla Palu. E-Jornal Katalogis. Vol. 3 No. 2: 2302-2019.

13. Pratwi, D., S., \& Suriani, L. (2017). Strategi Pemasran Produk Rangka Atap baja ringan pada PT. Hari Rezeki Kita Semua Pekanbaru. Vol. 3 No. 2.

14. Safitri, et al. (2016). Pengaruh Kualitas Pelayanan dan Citra Perusahaan Terhadap Kepuasan Pelanggan dan Loyalitas Pelanggan Service Center (Studi Pada Pelanggan Samsung Service Center di Kota Malang). Jurnal Ekonomi Bisnis. Vol. 21 No.1.

15. Setyowati, E., \& Wiyadi (2017). Pengaruh Kualitas Pelayanan, Harga, Dan Citra Merek Terhadap Loyalitas Pelanggan Dengan Kepuasan Pelanggan Sebagai Variabel Pemediasi. Jurnal Ekonomi Manajemen Sumber Daya. Vol. 18 No. 2.

16. Simamora, B. (2003). Memenangkan Pasar dengan Pemasaran Efektif \& Profitabel. Gramedia Pustaka Umum, Jakarta.

17. Sondakh, Conny. 2014. Kualitas Layanan, Citra Merek dan Pengaruhnya Terhadap Kepuasan Nasabah dan Loyalitas Nasabah Tabungan (Studi pada Nasabah Taplus BNI Cabang Manado). Jurnal Riset Bisnis dan Manajemen, Vol 3 No. 1.

18. Sugiyono. 2014. Metode Penelitian Bisnis, cetakan kedelapan. Bandung: Penerbit Alfabeta.

19. Suratno, et al. (2016). Pengaruh Citra Perusaahaan Dan Kualitas Pelayanan Terhadap Loyalitas Pelanggan Dengan Kepuasan Pelanggan Sebagai Variabel Intervening Pada Pt. Pelabuhan Indonesia Ii Semarang. Journal of Management. Vol. 2 No. 2

20. Tjiptono, F. (2011). Pemasaran Jasa. Malang: Bayumedia

How to cite this article: Rahayu HS, Ginting P, Fawzeea BK. The influence of service quality and company image to customer loyalty through corporate customer satisfaction on XXX Group. International Journal of Research and Review. 2021; 8(8): 207-213. DOI: https://doi.org/10. 52403/ijrr.20210829 